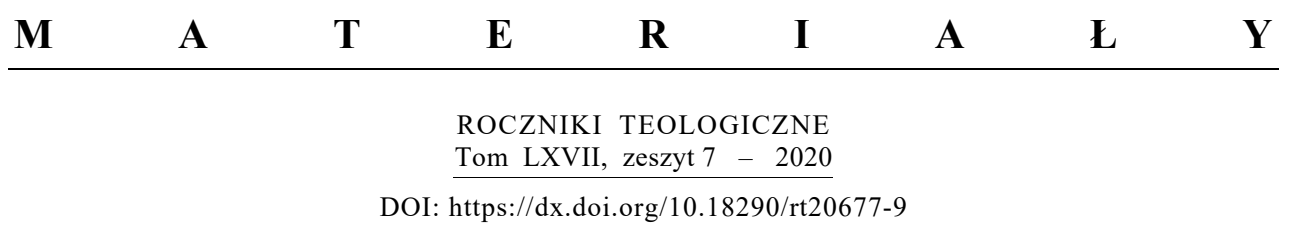

ABP GRZEGORZ RYŚ

\title{
NASZE ODNIESIENIE DO BRACI NIEKATOLIKÓW - MIŁOŚĆ I UCZCIWOŚĆ WE WZAJEMNYCH RELACJACH*
}

Niniejszą refleksję chciałbym oprzeć na trzech punktach adhortacji Evangelii gaudium $^{1}$, ponieważ spośród wszystkich dokumentów papieża Franciszka właśnie ten uważany jest za najważniejszy i programowy. $Z$ tych trzech punktów pragnę wyprowadzić cztery główne myśli dotyczące miłości i uczciwości w obszarze ekumenicznym.

Po pierwsze, miłość i uczciwość z naszej strony dotyczy najpierw Boga. Dlaczego? Dlatego, że ekumenizm - jak zaznacza papież Franciszek - jest najpierw odpowiedzią na testament Jezusowy (J 17,21), ale ekumenizm jest także wpisany w „wolne i hojne działanie Ducha"2. Nie chodzi więc jedynie o to, że przeczytaliśmy testament Jezusa i chcemy się zachować wobec niego z szacunkiem ze względu na zobowiązującą siłę ostatniej woli Syna Bożego, ale pragniemy również poddać się aktualnemu działaniu Ducha Świętego, który jest suwerenem w Kościele. Nieposłuszeństwo Słowu Bożemu i stawianie oporu działalności Ducha Świętego to brak miłości i uczciwości z naszej strony wobec Boga. Nie możemy odrzucać Jego mocy i miłości, jednocześnie przedstawiając siebie jako reprezentantów i pośredników Boga, których misja jest wpisana w jedyne pośrednictwo Jezusa Chrystusa. Powo-

Abp dr hab. GRZEGORZ RYŚ - arcybiskup metropolita łódzki, od 2020 r. administrator apostolski diecezji kaliskiej, członek Rady Stałej i Rady ds. Kultury i Ochrony Dziedzictwa Kulturowego Konferencji Episkopatu Polski. ORCID: https://orcid.org/0000-0001-8891-9182.

${ }^{*}$ Tekst referatu wygłoszonego podczas konferencji naukowej „Łaską jesteście zbawieni przez wiarę" (Ef 2,8), zorganizowanej 14 listopada 2019 r. na KUL przez Sekcję Ekumenizmu Instytutu Nauk Teologicznych na Wydziale Teologii KUL i Radę ds. Ekumenizmu Konferencji Episkopatu Polski w 20. rocznicę podpisania Wspólnej deklaracji na temat nauki o usprawiedliwieniu.

${ }^{1}$ Papież FranciszeK, Evangelii gaudium, Kraków: Wydawnictwo „m” 2013.

${ }^{2}$ Evangelii gaudium, $\mathrm{nr} 246$. 
łując się na Boga, a nie poddając się Jego myśleniu i Jego działaniu, postępujemy nieuczciwie. Boże prowadzenie jest procesem aktualnym i dynamicznym. Papież Franciszek przedstawia je w swojej adhortacji, mówiąc obrazowo o drodze. Mówi, że „powinniśmy zawsze pamiętać, że jesteśmy pielgrzymami i że pielgrzymujemy razem"3. Na początek warto by nie udawać, że jako katolicy jesteśmy u celu, ale uznać, że podobnie jak inni jesteśmy w drodze. Do zrozumienia tego postulatu konieczne jest pewne wyjaśnienie. Po pierwsze, warto sięgnąć do myśli Jana Pawła II z jego orędzia na Światowy Dzień Pokoju, w którym mówi: „Jedną z pokus powracających we wszystkich czasach również wśród chrześcijan jest uważanie siebie za depozytariuszy prawdy"4. Gdy przeczytałem ten tekst po raz pierwszy, to myślałem, że jest to jawna herezja. Zrozumiałem jednak, że choć prawda została nam zawierzona, to nie oznacza, iż nasz wykład i rozumienie tej prawdy jest doskonałe. To pozwala odeprzeć pokusę myślenia, że jesteśmy u celu, bo mamy zawierzoną prawdę. Drugi punkt jest jeszcze ważniejszy, a to dlatego, że celem tej drogi na której jesteśmy, wcale nie jest znajomość doktryny. Papież Franciszek mówi, że w czasie tej drogi mamy ,spoglądać tylko na to, czego szukamy: pokoju na obliczu jedynego Boga"5. Nie chodzi więc o znajomość pojęć i o wiedzę (co wcale nie oznacza, że są one nieważne). Celem naszej drogi jako Kościołów jest oglądanie jedynego oblicza Bożego i taka komunia z Bogiem, która przynosi pokój między nami. To jest prawdziwy cel drogi, nie zaś jedynie znajomość doktryny. Stąd pada postulat papieża Franciszka, że „należy powierzyć serce towarzyszowi drogi bez nieufności i bez uprzedzeń"6. Być może mielibyśmy prawo do uprzedzeń albo do nieufności wobec siebie, ale to, co znosi te nieufność i uprzedzenia, to fakt wspólnej wędrówki. To bardzo piękny obraz Kościoła, który jest pielgrzymujący. Podczas wspólnej drogi bardzo istotne jest to, z kim idziesz, wytwarza się bowiem wzajemna zależność. Niesłychanie istotne jest zaufanie - należy „zawierzyć serce” towarzyszowi drogi. Takie powierzenie serca jest „rękodziełem”. Na Synodzie biskupów na temat młodzieży jeden $\mathrm{z}$ azjatyckich biskupów mówił, że nasza praca z młodymi powinna być rękodziełem, a nie linią produkcyjną.

\footnotetext{
${ }^{3}$ Evangelii gaudium, $\mathrm{nr} 244$.

${ }^{4}$ JAN PAWEe II, Poszanowanie sumienia każdego człowieka warunkiem pokoju. Orędzie Jana Pawła II na XXIV Światowy Dzień Pokoju, https://papiez.wiara.pl/doc/378718.Poszanowaniesumienia-kazdego-czlowieka-warunkiem-pokoju-1991/6, nr 8.

${ }^{5}$ Evangelii gaudium, $\mathrm{nr} 244$

${ }^{6}$ Polski tekst wiernie oddaje tekst włoski. W niektórych przekładach na języki nowożytne nie ma „powierzyć serce”, ale „zaufać”, „zawierzyć”, co sprawia, że ten poetycki tekst staje się uboższy.

${ }^{7}$ Evangelii gaudium, $\mathrm{nr} 244$
} 
Powierzamy swoje serce towarzyszowi drogi w pielgrzymce, jaką jest droga wiary Kościołów, aby odkryć oblicze Boga i pokój, który ona przynosi. Oznaczałoby to, że wspólne pielgrzymowanie ma charakter indywidualny, głęboko osobisty i nie poddaje się logice linii produkcyjnej (jednego modelu dla każdego spotkania), ale jest bliskie temu, co dzisiaj jest niemalże refrenem w języku Kościoła, tzn. towarzyszeniem. Towarzyszenie to skoncentrowanie się na osobie, z którą idę. To jest pierwszy wymiar miłości i uczciwości. Myślę, że w ekumenizmie najpierw liczy się miłość i uczciwość względem Pana Boga. Jeśli tego w nas zabraknie, to wszystko inne jest nawoływaniem siebie do miłości i uczciwości, która nie wykracza poza tanią, moralizatorską manierę.

Drugim wymiarem jest „miłość i uczciwość wobec rodziny ludzkiej”». Dlaczego jest ona ważna i warto o niej mówić w dialogu ekumenicznym? Papież Franciszek wpisuje rozważania o dialogu ekumenicznym w większą całość, zatytułowaną „Dialog społeczny jako wkład na rzecz pokoju”. Papież mówi, że „ekumenizm jest wkładem w jedność rodziny ludzkiej”"10. W pierwszej chwili można odnieść wrażenie, że chrześcijaństwo zostaje tutaj poddane jakiejś instrumentalizacji. Chodzi jednak raczej o to, co jest wpisane w definicję Kościoła sformułowaną podczas Soboru Watykańskiego II w Konstytucji dogmatycznej o Kościele Lumen gentium: „Kościół jest w Chrystusie niejako sakramentem, czyli znakiem i narzędziem wewnętrznego zjednoczenia z Bogiem i jedności całego rodzaju ludzkiego" ". Choć trudno mówić o definicji, gdy zaczyna się od słowa ,jakby” i można nabrać pewnego dystansu, to jednak użycie słowa ,jakby" w tym przypadku wskazuje i podkreśla, że Kościół jest trudno definiować w sposób ścisły. Jeśli jest on jednak definiowalny, to właśnie jako sakrament, który jest skutecznym znakiem niewidzialnej łaski. Ta niewidzialna łaska przekłada się na wewnętrzne zjednoczenie z Bogiem i zjednoczenie całego rodzaju ludzkiego. Papież Franciszek podkreśla więc konieczność wypełniania misji, jaka jest wpisana w samą definicję Kościoła i stanowi naszą deklarację wobec świata, iż chcemy być narzędziem jedności całego rodzaju ludzkiego. Niestety, jak zauważa papież Franciszek, jest inaczej, gdyż podziały występujące między chrześcijanami powodują najczęściej zaostrzenie podziałów społecznych czy politycznych ${ }^{12}$.

\footnotetext{
${ }^{8}$ Evangelii gaudium, $\mathrm{nr} 245$.

${ }^{9}$ Evangelii gaudium, $\mathrm{nr} 238-258$.

${ }^{10}$ Evangelii gaudium, nr. 245.

${ }^{11}$ Lumen Gentium, $\mathrm{nr} 1$.

${ }^{12}$ Jednym z nieodległych przykładów może być konflikt na Bałkanach.
} 
Swoją misję budowania jedności całego rodzaju ludzkiego Kościół może spełniać bardziej przez to, kim jest, niż przez to, co mówi lub działa. Ksiądz Franciszek Blachnicki częstokroć powtarzał, że nikt nie daje tego, czego nie posiada. Nie można być znakiem jedności, jeśli samemu nie ma się tej jedności w sobie. Nie można być skutecznym narzędziem jedności, nie otwierając się najpierw do wnętrza. To dobrze komponuje z lineamentami, które poprzedziły synod o nowej ewangelizacji dla przekazu wiary chrześcijańskiej ${ }^{13}$, gdzie przekonywano jego uczestników, że ewangelizacja jest tak naprawdę kwestią eklezjologiczną. W ewangelizacji nie można komuś dać jedynie teorii i książki, ale trzeba go wprowadzić do wspólnoty. Do jakiej wspólnoty ośmielamy się wprowadzić człowieka, który przyjmuje Jezusa jako Pana i Zbawiciela? Do takiej, która jest pozbawiona wewnętrznej jedności? Zamiast być narzędziem jedności całego rodzaju ludzkiego, jesteśmy zgorszeniem dla tych, którym przepowiadamy wiarę ${ }^{14}$. Mówimy ludziom, że chcemy być narzędziem ich jedności, a następnie jesteśmy tymi, którzy albo potwierdzają, albo wręcz zaostrzają istniejące między ludźmi podziały. To nie tylko jest nieuczciwe, ale także pozbawione miłości.

Z tego wynika trzeci punkt, czyli miłość i uczciwość we wzajemnych relacjach. Istotne jest przede wszystkim to, kim jesteśmy jako jeden Kościół Pana. W tym obszarze papież Franciszek wskazuje na kilka istotnych rzeczy. Po pierwsze, zauważa, że jest między nami miłość i uczciwość, kiedy ekumenizm nie jest czystą dyplomacją i działaniem pod przymusem. Jedno i drugie może zachodzić np. wtedy, gdy przeżywamy tydzień modlitw o jedność chrześcijan. Jeśli jest to tylko czysta dyplomacja i przymus, to trudno mówić o ewangelicznych owocach. Żeby ekumenizm nie był czystą dyplomacją i działaniem pod przymusem, musi być „nieodzowną drogą ewangelizacji" "15. Wynika to najgłębiej ze stwierdzenia papieża Pawła VI z Evangelii nuntiandi, w którym stwierdza, że „Kościół jako głosiciel Ewangelii,

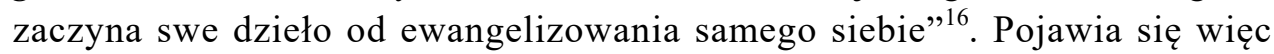
pytanie jaką mamy wizję eklezjologiczną i co mamy na myśli gdy mówimy „Kościół”? Jak rozumiany Kościół jest podmiotem ewangelizacji? W praktyce często jest tak, że każdy robi swoją ewangelizację i ekumenizm nie jest

\footnotetext{
${ }^{13}$ Nowa ewangelizacja dla przekazu wiary chrześcijańskiej, Watykan 2012, http://www.vatican.va/ roman_curia/synod/documents/rc_synod_doc_20120619_instrumentum-xiii_pl.pdf.

${ }^{14}$ Por. Evangelii gaudium, $\mathrm{nr}$ 244-246.

${ }^{15}$ Evangelii gaudium, $\mathrm{nr} 246$.

${ }^{16}$ Pawet VI, Evangelii nuntiandi. Adhortacja apostolska o ewangelizacji w świecie wspótczesnym, Wrocław: Wydawnictwo TUM 1975, nr 15.
} 
do niczego potrzebny. Papież Franciszek, określając ekumenizm jako „nieodzowną drogę ewangelizacji”, wskazuje, że nie może być w nim jedynie czystej dyplomacji i przymusu. Kościół istnieje wyłącznie z racji na ewangelizację i nie ma innego celu i powodu, by Kościół istniał.

Miłość i uczciwość we wzajemnych relacjach wymagają także wzajemnego poznawania się. „Nie chodzi tylko o otrzymanie informacji o drugich, by ich lepiej poznać" ${ }^{17}$. Sama informacja jest potrzebna, a jej wartość jest jeszcze większa, gdy mamy ją od siebie nawzajem. Informacja jest jednak dopiero wstępem do rzeczywistego poznawania siebie. Następnym etapem, gdy już coś o sobie wiemy i przestaliśmy się siebie nawzajem bać, jest wspólne „głoszenie przesłania, służba i świadectwo”18. Papież Franciszek, podając przestrzenie, które mogą być wspólne, wskazuje na trzy istotne warunki. Po pierwsze, koncentracja na tym, co jest nam wspólne. Po drugie, pamięć o zasadzie hierarchii prawd ${ }^{19}$. Ostatnim zaś, ale i najważniejszym warunkiem jest wspólne przekonanie, że ekumenizm polega na wymianie duchowych darów ${ }^{20}$. Nie jest tylko wzajemną wiedzą o sobie, ale jest wymianą duchowych darów. Papież Franciszek używa w Evangelii gaudium trochę innego obrazu, mówiąc, że trzeba zebrać razem wszystko to, co Duch rozsiał w innych Kościołach. Niezależnie od tego, z którego jestem Kościoła, a uznając prawdę, że Duch sieje w różnych wspólnotach także dla mnie, mam prawo korzystać z Jego owoców.

Podsumowując, należy zaznaczyć, że miłość i uczciwość jest potrzebna także wobec siebie samego. Jeśli coś deklarujemy, a potem nie ma to żadnego przełożenia na nasze myślenie i działanie, to wykonujemy krok nie do przodu, ale do tyłu. Rozważając te trzy punkty Evangelii gaudium, trzeba dalej podjąć wysiłek wprowadzenia ich w życie. W innym wypadku ekumenizm stanie się jednym z takich obszarów życia (w Kościele katolickim, nie ośmieliłbym się mówić o innych), w którym nie nadążamy za własną teologią i nauczaniem. Choć całe nauczanie jest precyzyjne i piękne, to rodzi się pytanie: kiedy przełoży się ono na nasze myślenie i działanie? Uczciwość i miłość do samego siebie wymagałaby nie tylko, aby przeczytać przywołane

\footnotetext{
${ }^{17}$ Evangelii gaudium, nr 246. Papież Franciszek używa wprost słowa „informacja”, być może wynika to z faktu, że żyjemy w kulturze informacji.

${ }^{18}$ Evangelii gaudium, $\mathrm{nr} 246$.

${ }^{19}$ Jest to niesłychanie ważna zasada. Jednym ze sposobów przepowiadania kerygmy jest kurs Alpha. Często, gdy się o nim wspomina, to pojawia się protest (np. „tam nie ma nic o Matce Bożej”). W ciągu jednak dziesięciu spotkań zgodnie z zasadą hierarchii prawd mówi się o tym, co jest najistotniejsze, nie umniejszając innych spraw.

${ }^{20}$ Tak ekumenizm definiują papieże począwszy od św. Jana Pawła II.
} 
dokumenty Soboru Watykańskiego II, lecz także, aby ich treść stała się programem mojego myślenia i działania nawet za cenę niezrozumienia ze strony niektórych naszych sióstr i braci.

\section{BIBLIOGRAFIA}

FrANCISZEK: Evangelii gaudium, Kraków: Wydawnictwo „m” 2013.

JAN PAweŁ II: Poszanowanie sumienia każdego człowieka warunkiem pokoju. Orędzie Jana Pawła II na XXIV Światowy Dzień Pokoju, https://papiez.wiara.pl/doc/378718. Poszanowanie-sumie niakazdego-czlowieka-warunkiem-pokoju-1991/6.

Nowa ewangelizacja dla przekazu wiary chrześcijańskiej, Watykan 2012, http://www.vatican.va/ roman_curia/synod/documents/rc_synod_doc_20120619_instrumentum-xiii_pl.pdf

PAWEe VI: Evangelii nuntiandi. Adhortacja apostolska o ewangelizacji w świecie współczesnym, Wrocław: Wydawnictwo TUM 1975. 